\title{
Challenges and Opportunities of Internship Lessons in the View of Students from Farhangian University Case Study: Colleges of Pardis Fatemeh Zahra and Shahid Rajai in Esfahan
}

\author{
Neda Parishani1 \\ Pooran Khorooshi²

\begin{abstract}
${ }^{1} \mathrm{PhD}$ Student of Curriculum( and Visiting Educator to Farhangian University), Department of education, Faculty of Psychology and Education, University of Isfahan, Isfahan, Iran .Corresponding author Email:ne.parishani@ymail.com 2Tutor in Pardis Fatemeh Zahra College, Farhangian University, Isfahan, Iran
\end{abstract}

Doi:10.5901/mjss.2016.v7n5p143

\begin{abstract}
Purpose of this study was to examine the challenges and opportunities of Internship Lessons in the view of students from Farhangian University (Pardis Fatemeh Zahra and Shahid Rajai Colleges). The methodology was qualitative and in order to achieve the objective, semi-structured interviews have been done over 30 students. Interviews were analyzed after the implementation and application of MAX.QDA 2007. The results showed that in the view of the students there were the challenges in the intern lessons in the syllabus, objectives, contents, teaching-learning strategies, evaluation methods, time and space assigned to this course. Also in the running, components of in-service training of teachers, interaction between Education Department and Farhangian University, how to collaborate principals and teachers in schools and teachers and students, lack of common understanding of the training course and negative attitudes of some teachers, the way from schools to universities have possessed some problems. Given opportunities created in the course of student, teachers believed that this course has affected the domains of knowledge, skills and attitudes of them. But the skills learned in this course have been very prominent.
\end{abstract}

Keywords: Internship, Farhangian University, Challenges, Opportunities, Students.

\section{Introduction}

Teacher training universities including Farhangian University can be regarded as the most important components of the education system, because success and failure in transforming the educational system depends on empowering teachers and creating professional capacity for them who are actually the principal executors of programs in the real environment (Bibisoltani \& Jabalamoli, 2012). Therefore, the teacher training system should provide the skills and knowledge required for success in this new era (Veil, 2010), and the curriculum of Farhangian University should be consistent with the changes and developments in society (Doyran, 2012). In particular, it is necessary to pay attention to the practical education and training of teachers in universities with regard to the new challenges (Bibisoltani \& Jabalamoli, 2012).

Designing "Teacher Training Centers' Curriculum with competency-oriented approach" requires putting internship at the heart of educational practice and extending it to all lessons and learning assignments. The fulfillment of the competencies envisaged in the National Curriculum of Teacher Training Centers is contingent upon the execution of the internship program (Ahmad Abadi, 2013). Internship is a common term in the field of experiential education or experiential learning that may occur in different seasons and includes cooperative learning, independent learning, and learning with support from the college (Bukglia, 2012). In fact, university internship is a kind of experiential learning that integrates knowledge and academic theory with application and skills in the workplace.

According to Queen 2002 and Rhlling, internship is a bridge between academia and the business environment (Ruhanen et al., 2013). Schouan thinks internship is an environment where practical learning happens and students learn by doing. Internship is in fact the pattern of thinking in action in which thoughtful interns are trained (Salerni, 2013).

In internship program, by understanding theoretical foundations, students will be able to support the decisions taken in educational settings by providing evidence of scientific research / findings and show how these decisions enjoy theoretical background in planning, implementation and evaluation to support the learning. They should be obliged in the teaching practice to create a plan, determine how to implement it and evaluate it and by rethinking about the learning activity, find the cause of their success or failure and if necessary, formulate, implement and evaluate the program once 
again (Raouf, 1996, p. 5).

Internship is considered an opportunity for students to become familiar with the work environment and not only enhances their capabilities for future employment but also gives interns a wider choice in their tasks so that they can find about their interests and tendencies better and evaluate the strengths and weaknesses of their work.

In other words, theoretical principles can be taught in the classroom in the best way, but real communication methods can be achieved only through practice and it is at the action stage that interns are able to communicate verbally and increase verbal and non-verbal communication skills. It is in the internship course that students can achieve professional development.

Nico (2015) concluded in his study that there is an intrinsic relationship between the quality of teacher training in practical lessons (Internship) and students training. Arefi, Fathi Vajargah and Naderi (2009), Shahpasand (2008); Buczynskils, \& Hansen (2010), Fielder (2010); Garet, Porter, Desimone, Birman \& Yoon (2001); Nir \& Bogler (2008); and Richter et al. (2011) focused in their studies on the need for the professional development of teachers.

However, the internship course is unfortunately not taken seriously in the higher education system of Iran. It seems that the reason for this is students' lack of familiarity with the need for job preparation at the college as well as their lack of awareness of the vital role that internship plays in job preparation (Naimplay et al., 2011) and the lack of appropriate curriculum for students. Farhangian University designed and implemented the new curriculum of the internship course in the school year 2013-14. New curriculum emphasis in reflective observation, narrative writing and analysis experience as constructive elements/ shaping ContemplationIn. In new internship course used triple tools: action research lesson Study and research narrative as a method. Considering the importance of the internship course, the present study attempts to evaluate the challenges and opportunities for the internship course (Internship 1 to 4) from the perspective of the university students of Farhangian Universities of Fatemeh Zahra (SA) and Shahid Rajai Isfahan.

\section{Research Question}

1. What are the challenges and opportunities of the internship course at Farhangian University from the perspective of students?

\section{Research Method}

This is a descriptive - analytic research. The qualitative approach has been used in this study for data collection. In order to collect information, we conducted semi-structured interviews with students who had passed this course. The population included 17 students from the campus of Fatima Zahra and 13 students from Shahid Rajaei Higher education center. Table 1 shows the frequency of demographic features of this research population. The sampling method used in the research was purposive chain sampling (Nasr et al., 2007: 393). In order to determine the validity and reliability of the interview, we used content validity and the content analysis was made using MAX.QDA Software Version 2007. At first reading of the interviews texts the researcher listened to them many times to be able to extract the basic meaning. After two interviews, the coding and categorizing began. The interviews were examined line by line and the meaningful sentences related to major questions of the study were signed. The basic concepts of meaningful sentences were extracted in codes, entered in the software and categorized. The codes including a common concept were put in one class. The researcher's job in classifying and reviewing the classes was continued up to the convincement regarding created classes. Afterwards, for each class (depending on the concept the class involves) a name was allocated. It should be mentioned that this job was done for all interviews. To get to the reliability, the method of recoding by the judges was used.

Table 1: Frequency distribution of interviewed people

\begin{tabular}{lcccl}
\hline Farhangian University & Number & Gender & Age range & Education \\
\hline Fatima Zahra & 17 & Female & $20-22$ & Student in Education \\
Shahid Rajaei & 13 & Female & $20-22$ & Student in Education \\
\hline
\end{tabular}




\section{Findings}

\subsection{Challenges of the internship course}

After conducting interviews with student teachers in relation to the challenges of the internship course and their content analysis, we could obtain the following data.

Table 2: Challenges of the internship course from the student teachers' perspective

\begin{tabular}{|c|c|c|c|c|}
\hline \begin{tabular}{|l|} 
Selective codes \\
\end{tabular} & Axial codes & Open codes & categories & Propositions \\
\hline \multirow{6}{*}{ Curriculum } & Goals & Idealistic look & - & Too high expectations \\
\hline & Content & $\begin{array}{l}\text { - Sequence of the } \\
\text { curriculum } \\
\text { - The required } \\
\text { content } \\
\text { - Too many } \\
\text { assignments } \\
\text { Less related courses }\end{array}$ & $\begin{array}{l}\text { Lack of access to } \\
\text { the problem at } \\
\text { school } \\
\text {-assignment }\end{array}$ & $\begin{array}{l}\text { Not passing the prerequisite courses } \\
\text {-the existence of few issues in higher schools } \\
\text {-The manager's and assistant's lack of experience and } \\
\text { attendance in the meetings } \\
\text {-Assignments not proportional to the course } \\
\text {-Action research is merely a writing assignment in } \\
\text { practice, not an executive one. } \\
\text {-Too much work for a student during a semester } \\
\text {-Repeated report-writing and encoding } \\
\text { The existence of courses such as painting and physical } \\
\text { education in days of internship }\end{array}$ \\
\hline & \begin{tabular}{|l|} 
Learning/teaching \\
strategies
\end{tabular} & - & - & $\begin{array}{l}\text {-Lack of mastery over the teaching methods of certain } \\
\text { textbooks such as math. }\end{array}$ \\
\hline & $\begin{array}{l}\text { Evaluation } \\
\text { methods }\end{array}$ & $\begin{array}{l}\text {-Evaluation of } \\
\text { courses }\end{array}$ & $\begin{array}{l}\text {-Professors } \\
\text {-Manager and } \\
\text { assistant teacher }\end{array}$ & $\begin{array}{l}\text {-The professors' lack of coordination in evaluation } \\
\text { methods. } \\
\text {-the mismatch of the manager's and the assistant } \\
\text { teacher's evaluation of student teachers with the } \\
\text { internship goals } \\
\text {-The manager and assistant teachers' lack of knowledge } \\
\text { about the student teachers' way of evaluation }\end{array}$ \\
\hline & Time & $\begin{array}{l}\text { Spending too much } \\
\text { time }\end{array}$ & & $\begin{array}{l}\text {-Shortage of time in Internship 1, } 2 \text { and } 3 . \\
\text {-Presence for one day per week. }\end{array}$ \\
\hline & Space & & $\begin{array}{l}\text { Smallness of the } \\
\text { classroom space }\end{array}$ & Lack of good space for students in the classroom \\
\hline Executive issues & & $\begin{array}{l}\text {-Managers } \\
\text {-Time } \\
\text {-distance } \\
\text {-Teachers }\end{array}$ & $\begin{array}{l}\text {-Education } \\
\text {-Lack of enough } \\
\text { motivation } \\
\\
\\
\\
\text { The assistant } \\
\text { teacher's negative } \\
\text { attitude } \\
\text { The teacher's } \\
\text { artificial behavior }\end{array}$ & $\begin{array}{l}\text { - the manager's lack of familiarity with the practical } \\
\text { process of the course, } \\
\text { - the manager's lack of proper cooperation, } \\
\text { - the manager's assigning office tasks or cleaning to } \\
\text { student teachers, } \\
\text { - the manager's prevention of the plan implementation in } \\
\text { school } \\
\text { - holding the class in the university after presence in } \\
\text { school } \\
\text { - the existence of a long distance between school and } \\
\text { university } \\
\text { - lack of timely submission of the license of student } \\
\text { teachers' presence to schools } \\
\text {-the teachers' lack of information about the internship } \\
\text { course", } \\
\text {-the teachers' lack of motivation for cooperation, } \\
\text {-the shortage of good teachers from whom student } \\
\text { teachers to learn, } \\
\text { - the teachers' lack of familiarity with the practical process } \\
\text { of the internship course, } \\
\text { - the teachers' lack of good cooperation, teachers' lack of } \\
\text { good communication with internship, } \\
\text { - the teachers' assigning incomplete tasks to interns, } \\
\text { - the teachers' feeling that the students are spying in their } \\
\text { classes, } \\
\text { - artificial interactions between the teacher and students }\end{array}$ \\
\hline
\end{tabular}




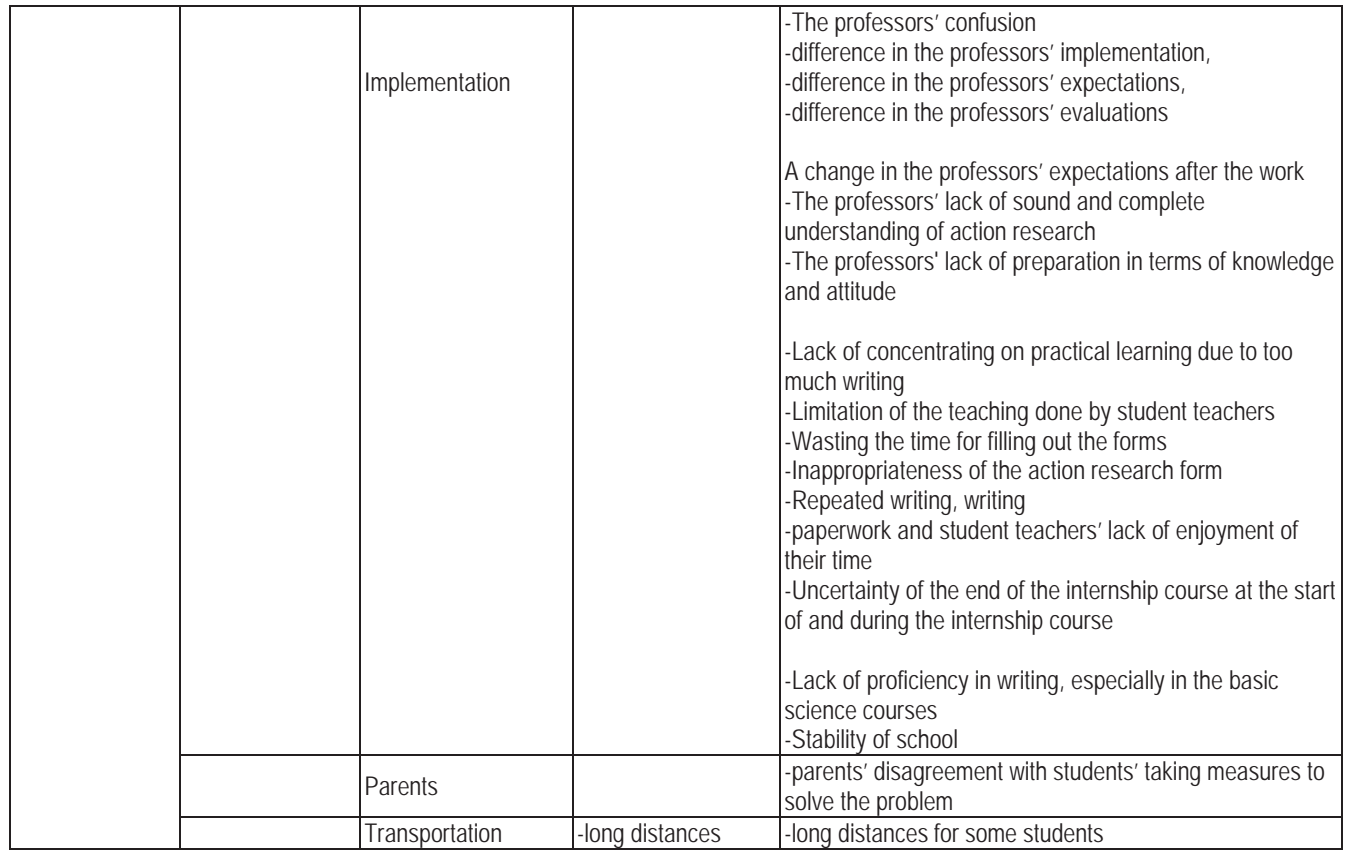

As specified in Table 2, the results of the interviews conducted with the students are categorized into two areas: 1 . Curriculum, and 2. Implementation

1. The curriculum area: In this area, the problems include the following components: goal, content, teaching/learning methods, evaluation, time and space.

After analysis of the content of the interviews with student teachers of the internship course, the components obtained regarding goals were too high expectations from the students, which demanded many goals from the students during a semester.

The content of the curriculum: After analysis of the content of the interviews conducted with student teachers, the categories obtained were the sequence of the curriculum (non-compliance with the prerequisite courses), the content of the curriculum, too many assignments and the existence of courses unrelated to the internship course. In relation to the curriculum content, the interviewee number six said about the lack of a proper sequence in curriculum and the students' not passing the prerequisite courses:

I do not have mastery over the math and science books at all, so I can't think of the students' problems in these textbooks. I inevitably talk about the Persian textbook. I have courses related to the teaching methods of these courses this semester, whereas I should have had them in the last semester.

Interviewee number one said in relation to the great amount of work and its effect on their health:

I chose this field as it was my field of interest and was fond of the internship course and was very eager to go to school to communicate with kids I loved, teach them, and be an intimate friend with them. But now, I don't have that motivation and have to say that I have actually become disappointed. To tell the truth, because of so much pressure of this course and hard work, I am anxious that I see the nightmare every night and wake up at midnight. That's why I have seen a doctor.

Component of teaching-learning strategies: After analysis of the content of the interview, the issue of lack of proficiency in teaching subjects such as math was obtained.

Evaluation component: In relation to the evaluation component, the interviewees complained about the lack of cooperation between the professors of the internship course in evaluation methods and the mismatch of the manager's and the assistant teacher's evaluation of student teachers with the internship goals.

Time component: After analyzing the content of the interviewees, the issue of lack of time was obtained in internships 1, 2 and 3. For example, Interviewee NO. 18 said in relation to the limited time of the internship course:

The time of the internship course is not a good time. This course should be held two days a week. You know in a 
week there happens a lot that we remain unaware of. You shouldn't expect us to find challenges in the classroom, encode them, and then design work. We're one week away from the student and the teacher and the school. An intern should go to school at least two days a week.

Space component: After examining and analyzing the content of the interviews, it was shown that students lack enough space in the classroom.

Implementation component: In relation to the way of implementation, after analysis of the content of the interviews, the components: manager, time, Education, teachers, professors and parents were obtained.

Managers: after analysis of the interviews with student teachers of the internship course, the categories obtained included the manager's lack of familiarity with the practical process of the course, the manager's lack of proper cooperation, the manager's assigning office tasks or cleaning to student teachers, and the manager's prevention of the plan implementation in school. For example, interviewer No. 25 said in relation to the evaluation of the manager:

We had to do reflective observation in internship 1 and didn't do any special activities in class. The manager and assistants considered us lazy and assigned us the school jobs like sorting the books in the school library and even cleaning the library and the laboratory.

Time and distance components: After the content analysis, the categories "holding the class in university after presence in school" and "the existence of a long distance between school and university" were obtained.

Education component: After the content analysis, the category "lack of timely submission of the license of student teachers' presence to schools" was obtained.

Teachers: After the content analysis of the interviews conducted with student teachers of the internship course, the categories obtained are as follow: "teachers' lack of information about the internship course", teachers' lack of motivation for cooperation, the shortage of good teachers from whom student teachers to learn, teachers' lack of familiarity with the practical process of the internship course, teachers' lack of good cooperation, teachers' lack of good communication with internship, teachers' assigning incomplete tasks to interns, teachers' feeling that the students are spying in their classes, and artificial interactions between the teacher and students.. For example, interviewee NO 8 said in relation to the problem of the internship course with the assistant teacher:

My assistant teacher does not have a respectful relationship with me. I think I'm spying his class. It is very difficult for me. Interviewee Number twenty four also said: "The worst problem is that the school staff have not accepted interns and their identity and thus have an unpleasant behavior toward them.

Professors: After the analysis of the interview content, the categories obtained included the professors' confusion, difference in the professors' implementation, difference in the professors' expectations, difference in the professors' evaluations, a change in the professors' expectations after the task was done, the professors' lack of preparation in terms of attitude and knowledge, the professors' lack of sound and complete understanding of action research For example interviewee number twenty three said regarding the difference in the professors' evaluation:

Our professor took the reports from us every week, read them and got us to correct them. We had to correct them, which was of course a good thing. I want to say, we tried very hard, but there were classes in which students did not try at all, and if you read our report and compare them to theirs, you will notice the difference. However, we see that they have got excellent scores as well; it's true that our professor has given us good grades, but you cannot compare our efforts with others'.

Implementation component: After analysis of the interview, the categories obtained were as follow: writing too many reports of the classroom, lack of focus on practical learning, limitation of the teaching done by student teachers, wasting the time to fill out forms, inappropriateness of the form of action research, repeated writing , writing, paperwork and student teachers' lack of enjoyment of their time, uncertainty about the end of the internship course at the beginning and during the term, lack of mastery and proficiency in writing, especially in basic sciences courses, and instability of the school. For example, interviewee number 29 said about writing reports in the internship course:

These forms and reports do not benefit us at all and they're just a waste of time. Instead, they should hold courses for us on examining the books and I think that's more important than Forms A, B and C. It was better for them to teach us how to teach and examine books instead of writing reports so that we could manage the class better in future.

Parents: After the content analysis, the category 'parents' disagreement with students' taking measures to solve the problem.

\section{Opportunities of the Internship Course}

After conducting interviews with student teachers about opportunities of the internship course and their content analysis, the following data were obtained. 
Table 3. Opportunities created in the internship course from the students' perspective

\begin{tabular}{|c|c|c|c|}
\hline Selective code & Axial code & Open code & proposition \\
\hline \multirow{3}{*}{$\begin{array}{l}\text { Teaching } \\
\text { competencies }\end{array}$} & \multirow{3}{*}{$\begin{array}{l}\text { Promotion } \\
\text { of ability }\end{array}$} & knowledge & $\begin{array}{l}\text { - familiarity with the problems before attending schools } \\
\text { - the student teachers' achieving tacit knowledge through } \\
\text { analysis of one's experiences } \\
\text { - familiarity with the content of the courses }\end{array}$ \\
\hline & & Attitude & $\begin{array}{ll}\text { - } & \text { Turning point for starting teaching } \\
\text { - } & \text { An in-depth view due to report writing } \\
\text { - } & \text { building self-confidence } \\
\text { - } & \text { an overall complete perspective about one's profession }\end{array}$ \\
\hline & & Skill & $\begin{array}{l}\text { - A growth in the student teachers' ability of decision-making in } \\
\text { the teaching context. } \\
\text { - resulting in a professional person } \\
\text { - discovering the profession, the educational setting and building } \\
\text { a relationship between oneself and one's job } \\
\text { - holding seminars in the university and criticizing each student's } \\
\text { method of teaching by others } \\
\text { - student teachers' familiarity with teaching } \\
\text { - achieving experience in the real environment and facing of } \\
\text { problems and trying to meet them. } \\
\text { - determining our strengths and weaknesses and character } \\
\text { - integrating theory and practice } \\
\text { - connecting the content of the courses with issues of the day. }\end{array}$ \\
\hline
\end{tabular}

After analysis of the content of the interview conducted with the students of Shahid Rajaei Campus and Hazrat Fatemeh (S) Campus, it was shown in Table 3 that the internship course has created opportunities for promotion of teaching competencies in the components knowledge, attitude and skill. As shown in Table 3, this course has promoted the students' skills, has been effective in their attitude and has added a little to their knowledge. For example, interview number 17 said about the promotion of their knowledge in the internship course: "I was not familiar with the content of textbooks and didn't become familiar with the content of these books in any course; however, the internship course provided me with an opportunity to become familiar with the content of textbooks."

In relation to the effect of the internship course on the effects on student teachers', interviewee NO. 6 said: "Based on the tasks assigned to us and the reports asked of us at the end of each semester, we could get an overall and complete view about our career, the difficulty of the assigned responsibilities and our jobs' value."

In relation to the skill component, interview NO. 30 said: the internship course has contributed to our decisionmaking ability in educational settings and has made "professionals" from us students. Alluding to another skill in the internship course, he said: "the internship course has contributed to our discovery of our profession, the educational setting and establishment of a relationship between us and our jobs".

\section{Discussion and Conclusion}

We explored in this study the challenges and opportunities of the internship course from the perspective of student teachers of Shahid Rajai campus and Fatima Zahra Campus. The findings suggest that this course has many problems. The main problems identified about this course were categorized into two general classes of curriculum and implementation, each of which had separate components. The components of curriculum include objective, content, teaching-learning methods, evaluation, time and space. Based on analysis of the content of the interviews, the students of internship believed that regarding objectives, the expectations from the students were too many and to some extent beyond their ability. The prerequisite courses were not observed in the content of the internship course and the expected reports in this course are so many that make the students anxious. Moreover, the professors do not have enough mastery over the teaching methods and there is not enough coordination among the professors. Administering this course is very time-consuming as it is a wide subject. On the other hand, the time dedicated to this course is very limited and thus not proportional to the course. Considering the findings of this part (curriculum), it is necessary that fundamental revisions be made in the curriculum of the internship course. A particular attention has to be made to the depth and scope of the curricula of the teacher training centers including the internship course. The curriculum should be flexible enough and the objectives should be accounted for explicitly. The expectations and results should be proportional to the students' 
capacities. These findings are in line with the results of the studies conducted by Bibisoltani and Jabalamoli (2012), Veil (2010), Ahmadabadi (2013) and Raouf (1996).

In addition, the analysis of the interviews in the implementation component also indicates the existence of many problems in this part, including: manager, time, teachers, professors, implementation, and parents. Some of these problems are: the manager's lack of familiarity with the practical process of internship, the manager's lack of proper cooperation, the manager's assigning administrative or cleaning tasks to student teachers, and the manager's prevention of the plan implementation in school, the existence of a long distance between the school and the university, the teachers' lack of motivation, lack of proper collaboration and so on. Therefore, measures are to be taken in this respect to improve the existing conditions and remove the problems. These findings are consistent with the results of the studies conducted by Ahmadabadi (2013), Raouf (1996) and Bibisoltani and Jamalamoli (2012). Buczynskils, \& Hansen (2010), Fielder (2010); Garet, Porter, Desimone, Birman \& Yoon (2001); Nir \& Bogler (2008); and Richter et al. (2011), Ruhanen et al. (2013), Salerni (2013) and Raouf (1996).

Regarding the opportunities created by the internship course, the student teachers believed that this course has affected them in the areas of knowledge, skill and attitude. However, the skills learned in this course are more impressive. Student teachers have been able in this course to increase their skills including the skills of decision-making in educational settings, creating professional beings out of themselves, preparation for entrance into the educational system, discovery of the educational issues and problems, integration of science and practice, and recognition of their own strengths and weaknesses.

The above-mentioned points can be summarized in the following way: the internship course has entered the curriculum of Farhangian University and has brought about new concepts, subjects and basics for the academic integration of theory and application with regard to the educational perspectives and is seeking the academic documentation of it using theory and monitoring it. This discourse includes the cultural, social, historical, and cognitive conditions of a specific thought about professional development which deals in detail with internship and examines the situational context of this phenomenon and different perceptions of it at a time as well as its change and development at a time. The success of internship is completed when theory and practice are connected and the professors of the internship course become familiar with the new knowledge and the global experience and achieve the ability to approach and connect the arenas of theory and practice. Achieving a great holistic view ensures the implementation of internship in the new style.

Thus, with regard to the results of the present study, the following suggestions are made in order to promote the internship course and meet the challenges facing this course: to promote training courses and meet the challenges of this course is offered:

a. Regarding the curriculum

1. Revising the course objectives of the internship course and making it real in accordance with the actual conditions of student teachers, the facilities of the education organizations and offices of the provinces and regions and the human resources of Farhangian University in each province;

2. Revising the curriculum of Farhangian University with regard to the prerequisite courses of the internship course;

3. Revising the curriculum of Farhangian University and adding to it the courses related to the new sciences and technologies needed in the internship course;

4. Adding the internship course in order to fit the content with the reports requested by student teachers in this course and building further relationship with the educational setting;

5. Reducing the expectation of filling in the forms, writing reports, and encoding;

6. Modifying the content of the internship course in order for the student teachers to experience school management, participation in Teachers Council Meetings and Parent-Teacher Council meetings, which have been neglected in the new curriculum of the internship course;

7. Revising the teachers' and assistants' evaluation forms to fit them with the internship course.

b- Regarding implementation

1. Making the managers and teachers familiar with the internship course and the expectations for this course before the start of the school year;

2. Encouraging the managers and assistant teachers to promote motivation;

3. Selecting before the start of the school year the experienced teachers who use modern methods of teaching in the classroom;

4. Selecting schools having an appropriate physical space for admission of student teachers;

5. Holding in-service training courses before start of the semester for professors of the internship course so 
that they can get a similar understanding of the implementation of this course at the end of the in-service training course;

6. The central organization's not sending a new form with new expectations during a semester of the internship course;

7. Monitoring the same implementation and evaluation of the internship course by professors;

8. Not holding seminars after the closure of schools;

9. Holding seminars every three or four weeks at the University;

10. Creating better interaction with the Education Department to solve the problems of student teachers;

11. Considering transportation services for student teachers.

\section{References}

Ahmadabadi, Z. (2013). Solutions for increasing the practical quality and teaching practice in education. The $8^{\text {th }}$ Seminar of Teaching Chemistry in Iran.

Arefi, M., Fathi Vajargah, K. \& Naderi, R. (2009). Academic and professional knowledge of primary school teachers in Hamadan city in terms of learning. Educational Innovations, 8, (30), 31-51.

Bibisoltani, N. \& Jabalamoli, Sh. (2012). A study of the problems of the internship course of the interns students of planning and industrial design in industries. Entrepreneur Journal, 32, 114-128.

Buczynskils,S. \& Hansen,C.B. (2010). Impact of professional development on teacher practice.Uncorering connection. Teaching and Teacher Education. 26, (3), 599-607.

Bukaliya, R. (2012). The potential benefits and challenges of internship programs in an ODL institution a case for the Zimbabwe open university. International Journal on New Trends in Education and Their Implications, 3 (1), 118-13.

Doyran, F.(2012). Research on teacher education and training athens institute for education and research. ISBN: 978-960-9549.

Fielder,A. (2010). Elementary school teachers attitudes toward professional development: A grounded theory study. Ed. D3417235, university of phoenix, United States. Arizona.

Gall, M., Borg, W., \& Gall, J. (1996). Educational research: An introduction. Longman.

Garet, M.S.,Porter,A.C., Desimone, L., Birman, B. F., \& Yoon, K.S. (2010). What makes professional development effectives? Results from a national sample of researcher. American Educational Research Journal, 38,(4), 915-945.

Naimpally, A., Ramachandran, H. and Smith, C. (2011). Lifelong Learning for Engineers and Scientists in the Information Age. Chapter10, Evaluation of Internships, ISBN: 978-0-12-385214-4.

Nicu,A. (2015). Policy and practice of initial teacher training. Procedia - Social and Behavioral Sciences, 180, 80 - 86.

Nir, A.E., \& Bogler, R. (2008). The antecedents of teacher satisfaction with professional developmental programs. Teaching and Teacher Education,24, (2).337-386.

Raouf, A. (1996). Teacher training and internship, Tehran: Shabek Publication.

Richter, d., Kunter, M., Klusmann,U., Ludrke,O. \& Baumert, j. (2011). Professional development across the teaching career.Teachers uptake of formal and informal learning opportunitres. Teaching and Teacher Education, 27(1), 116-126.

Ruhanen, L. a. (2013). A foreign assignment: internships and international students. Journal of Hospi-.Tality and Tourism Management,20, 1-4.

Salerni, A. (2014). Narrative witing and university internship program. Procedia social and Behavioral sciences,140,133-137.

Shahpasand, M. R. (2008). Determining the professional development components factors for the agricultural-Jihad trainers in Iranian training Centers. Agronomy Journal, 40, (81), 130-139).

Vail, Lisa, M. (2010). Teaching in the century. A theses submited to the university of north Carolina. Wilmingtone in partial fulfilment of the requirements for the degree of master of education. 